\title{
REFLEXÕES SOBRE A PÓS-MODERNIDADE COMO UM NOVO MOMENTO DA “SOCIEDADE” OU COMO IDEOLOGIA PARA OS MARXISTAS
}

\author{
REFLECTIONS ON POST-MODERNITY AS A NEW MOMENT FOR "SOCIETY” OR AS \\ IDEOLOGY FOR MARXISTS
}

Flavio Roberto Chaddad ${ }^{1}$

\begin{abstract}
RESUMO: Introdução: A pós-modernidade vem sendo tratada por alguns autores como um novo momento da sociedade. Objetivo: Analisar a pós-modernidade como um novo momento da sociedade ou como ideologia marxista. Metodologia: Este estudo pautou-se em uma pesquisa teórica e, como metodologia de análise, adotou-se o método crítico-dialético. Resultados: Ao analisar os textos discutidos verificou-se que, ao ser vista como um novo momento da sociedade, a pós-modernidade se comporta como um simulacro que contribui para velar a exploração e expropriação exercidas pelo capitalismo sobre o homem e a natureza. Conclusão: Os resultados mostraram que a pós-modernidade não é um novo momento da sociedade, mas uma ideologia conforme os marxistas.
\end{abstract}

Palavras-chave: Pós-modernidade. Ideologia Marxista. Sociedade.

ABSTRACT: Introduction: Postmodernity has been treated by some authors as a new moment in civilization. Objective: This article aimed to analyze postmodernity as a new moment in society or as a Marxist ideology. Methodology: For this purpose, this study was based on theoretical research and, as an analysis methodology, the critical-dialectical method was adopted. Results: When analyzing the texts discussed here, it was found that, when seen as a new moment in society, postmodernity behaves as a simulacrum that contributes to watch over the exploitation and expropriation exercised by capitalism on man and nature. Conclusion: The results showed that postmodernity is not a new moment in society, but an ideology for Marxists.

Keywords: Postmodernity. Marxist ideology. Society.

\section{INTRODUÇÃO}

Para muitos pensadores da época contemporânea, a razão herdada pela civilização ocidental está sendo abandonada em favor de um novo momento, que adjetivam como pósmodernidade. Porém, esta razão já, há muito tempo, vinha sofrendo críticas e vieses por

\footnotetext{
${ }^{1}$ Mestre em Educação pela PUC-Campinas; Mestre em Educação Escolar pela Universidade Estadual Paulista UNESP/Araraquara. Graduado em filosofia pela Universidade de Franca (UNIFRAN). E-mail: frchaddad@gmail.com.
} 
parte de vários pensadores modernos e contemporâneos, que buscavam estabelecer, muitas vezes, os seus limites diante do mundo e do homem.

Rousseau (2010) faz críticas à civilização, afirmando que ela corrompeu o homem natural, implícitas no mito do bom selvagem. Kant (1999) diz que é impossível para a razão conhecer o em si das coisas, a realidade é inacessível aos seres humanos. Tudo o que conhecemos depende das categorias do entendimento. Schopenhauer (1965; 2013), introduz em sua filosofia o conceito de vontade, que perpassa todos os seres e independe de nossa razão. Safranski (2012) afirma que ele antecipou em um século a psicanálise de Freud. Marx desvela o processo de produção capitalista e elabora conceitos como mais-valia, fetiche da mercadoria e de ideologia. Freud (1978) constrói o conceito de inconsciente. A razão humana representaria apenas a ponta do iceberg. Pensadores de orientação marxista, durante o século XX, como Adorno e Horkheimer (1999), bem como Marcuse (2015), fazem uma análise crítica de toda modernidade, afirmando ser necessária uma apropriação da lógica formal pela dialética, mostrando-se preocupados com a quantificação do mundo pela lógica formal e com a questão da subjetividade, que foi dissolvida pelos discursos da modernidade.

Mas, apesar destes filósofos fundamentarem-se em um viés humanístico, ancorando-se nas metanarrativas (metafísica ou ciência), as grandes expressões de explicação da realidade, eles não podem ter as suas ideias circunscritas a um mesmo denominador. Porém, compartilham uma questão de fundamental importância: interrogam a razão herdada desde Parmênides até a modernidade.

Nietzsche (2008; 2010), ainda no século XIX, vai romper com toda esta metanarrativa filosófica e cultivar o solo por onde germinará e se edificará o que um conjunto de pensadores denominam como época pós-moderna. Apesar de Habermas (2002) enfatizar que Nietzsche pode ser considerado moderno, Nietzsche (2010), com a sua pseudonarrativa, vai alçar voo e colocar em xeque todo o aparato metafísico e racional moderno, inclusive o ideal de homem e de valor construído há milênios - o ideal do homem verídico - edificado por Parmênides e que foi aperfeiçoado pela lógica formal. Segundo Azeredo-Dutra (2010), Nietzsche é o ponto de virada na modernidade. Porém, não só Nietzsche vai oferecer críticas e romper com este ideal de razão, que fincou sua raiz no ocidente e se espalhou para os quatro cantos do mundo. 
Uma corrente de pensadores, a partir de meados do século XX, vem questionando as metanarrativas e influenciando a sociedade mundial. Eles passaram a ser denominados de pós-modernos. Rompem com o aparato racional da modernidade, que sustenta a metafísica, a ciência, o social, o antropológico, o econômico e o político. Capra (1999; 2003; 2007), Derrida (1999), Guattari (2001), Feyerabend (2003); Foucault (2001; 2010; 2011; 2012), Lyotard (1999), Santos (2001; 2007; 2010), entre outros, são alguns exemplos de pensadores, que propõem a ruptura com a concepção de mundo, de homem, de método e de valor inscrita na modernidade. Esta visão de mundo, calcada na exacerbação da razão e em sua quantificação pela lógica formal, na dissolução dos processos subjetivos pela construção metafísica de um sujeito ideal - o homem verídico - e pela ênfase na oposição entre cultura e natureza, seria a causa dos grandes dilemas humanos: o da exploração e expropriação do homem, da exacerbação dos racismos e discriminações de toda espécie e da visão utilitária da natureza. Entre outras coisas, as suas críticas recaem, principalmente, no ideal de razão que a tudo pretendia conhecer e dominar - e de homem, que implicam na exclusão da questão subjetiva, que passa a ser negada em prol ao imperativo racional dos grandes sistemas.

Segundo Evangelista (2005), ao enfatizar as cartografias, os espaços moleculares de existência, o efêmero e o transitório, as biografias, enfim, ao privilegiar os processos subjetivos e a ruptura com a ciência e uma leitura totalizante da realidade, fundamentada pela raiz sana da modernidade - o marxismo - a pós-modernidade impede uma apropriação crítica da mesma e um projeto racional de desenvolvimento humano. Neste sentido, segundo Oliveira e Buchala (2007): "não se deve jogar a criança com a água do banho" (Oliveira; Buchala, 2007, p.19). Portanto, uma questão de fundamental é que a ciência, mesmo sendo dialética, pode oferecer uma leitura totalizante da realidade e, através de uma articulação entre a lógica formal com a lógica dialética, construir a possibilidade de seu planejamento e de emancipação humana.

Tendo em vista o embate entre o discurso moderno e o pós-moderno torna-se necessário realizar a seguinte problematização: será que os fundamentos ditos pósmodernos, que norteiam uma nova concepção de mundo e de homem, de método e de valor, representam um novo momento da sociedade mundial ou apenas uma ideologia na acepção marxista? 
Este trabalho teve como objetivo analisar a pós-modernidade como um novo momento da sociedade ou como ideologia no sentido marxista. É resultante de uma pesquisa teórica, de caráter bibliográfico. Os textos adotados para a sua fundamentação e sua construção pertencem a filósofos, aos seus comentadores, aos manuais de história da filosofia ocidental e a artigos de pesquisadores que estão relacionados de forma específica com a problemática e o objetivo aqui postos. Acredita-se que poderão trazer subsídios que permitirão povoar ainda mais o universo das respostas e/ou de questionamentos que os circunscreve. Para tanto, adotou-se como metodologia de análise o materialismo históricodialético.

Segundo Martins (1994), o materialismo histórico-dialético, elaborado por Marx, se apoia em uma concepção dinâmica da realidade e das relações dialéticas entre os sujeitos e objetos, entre conhecimento e ação, entre teoria e prática, em que se vislumbra, através da apropriação crítica do processo histórico, que se faz por meio dos predicados postos e negados, entre a tese e a antitese, a sua superação pela síntese do concreto empírico pelo concerto pensado, o que vem a significar, acima de tudo, a incorporação do imediato pelo mediato.

Com este olhar lançado sobre o problema e com o objetivo aqui traçados, esperouse caracterizar a pós-modernidade como um novo momento da sociedade ou apenas como ideologia para os marxistas.

\section{PÓS-MODERNIDADE: IDEOLOGIA MARXISTA OU NOVO MOMENTO DA SOCIEDADE}

Nesta seção, procurar-se-á esboçar o conceito de ideologia segundo Marx. A partir da construção deste conceito de ideologia, buscar-se-á apresentar as principais críticas à modernidade e analisar o projeto pós-moderno como um novo momento da civilização ou apenas uma ideologia.

\section{I. Início de conversa: o conceito marxista de ideologia}

O primeiro significado encontra-se no pensamento de Lênin e diz respeito a um ideal ao qual se toma partido para a realização de algum fim humanístico. Um segundo significado, que parte de Marx, refere-se a um estado ilusório, um estado de aparências e/ou de falsificação da realidade, que serve a determinados interesses, que estão acima dos 
interesses da maioria da população e da natureza. Segundo Löwy (2003), para Marx a ideologia é uma forma de falsa consciência, produzida pelo sistema, aonde os grupos financeiramente poderosos buscam dominar e conduzir o processo histórico, construindo-a de forma ilusória. Segundo Chauí (1995), as ideias falsificadas se transformam em ideologia:

\begin{abstract}
Um exemplo desse senso comum aparece no caso da "explicação" da pobreza, em que o pobre é pobre por sua própria culpa (preguiça, ignorância) ou por vontade divina ou por inferioridade natural. Este senso comum social, na verdade, é o resultado de uma elaboração intelectual sobre a realidade, feita pelos intelectuais da sociedade - sacerdotes, filósofos, cientistas, professores, escritores, jornalistas, artistas - que descrevem e explicam o mundo a partir do ponto de vista da classe a que pertencem e que é a classe dominante de sua sociedade. Essa elaboração intelectual incorporada pelo senso comum social é a ideologia. Por meio dela, o ponto de vista, as opiniões e as ideias de uma das classes sociais - a dominante e dirigente - tornam-se o ponto de vista e a opinião de todas as classes e de toda a sociedade (Chauí, 1995, p.174).
\end{abstract}

Lessa e Tonet (200I) afirmam que Marx, em seu texto A Ideologia Alemã, relaciona a ideologia com a alienação e mostra que para o senso comum há um Espírito do Mundo, que impede a compreensão da realidade pela razão, como fez ao desvelar como se processa a apropriação da riqueza. A ideologia, através da mistificação e simplificação da realidade, impõe para todos como as coisas são e que resta ao homem apenas submeter-se a esta fixação da atividade social. O termo Espírito do Mundo apara-se na ideia do Deus Histórico de Hegel. O homem aqui não tem intencionalidade, pois quem o conduz, de acordo com sua vontade, é este Espírito. Segundo Marcuse (1969):

A soberania do Espírito revela um mundo controlado pelas forças da história, em lugar de controlá-las. A história revela-se como um patíbulo aonde foi sacrificado: a felicidade dos povos, a soberania dos Estados e a virtude dos indivíduos (Marcuse, p.213, 1969).

Todas as manifestações humanas nada mais são que a manifestação do Espírito do Mundo. A máxima expressão deste Espírito é o Estado Burguês ou da Livre Iniciativa. Esta é uma ideologia. Não há a intencionalidade dos homens que, em conjunto, podem planejar e concretizar a sua história, pois a realidade é falseada ou falsificada por quem detém o poder. Esta falsificação está a cabo do que Marx denominou de superestrutura, que nada mais é que a expressão das instituições, que amparam o funcionamento do sistema, como as escolas, as leis, as religiões, etc. Assim, conforme Lessa e Tonet (20II): "a realidade se mostra como força objetiva acima de nós, que escapa ao nosso controle, contraria as nossas expectativas e aniquila nossos cálculos” (Lessa; Tonet, 20II, p.9o). Segundo estes autores afirmam: 


\begin{abstract}
A organização da sociedade em classes possibilitou, como se observa, um enorme desenvolvimento das forças produtivas, e este novo poder dos humanos frente à natureza não parece vir da cooperação entre os indivíduos, mas sim de algo estranho a eles e que, de cima, "dirige até suas vontades e seus esforços". As relações sociais criadas pelos seres humanos, o desenvolvimento das forças produtivas decorrente da própria história dos homens, "essa consolidação do nosso próprio produto como força objetiva" (...), nas sociedades de classe ocorrem "como uma força alienada, que existe fora" de nós - da qual não sabemos "de onde vem e a que se destina" e que, portanto, não podemos dominar. A crítica das alienações de Marx e de Engels tem uma precisa finalidade: mostrar "de onde" vêm e "a que se destinam" as alienações para que, conhecidas suas raízes históricas, as possamos confrontar como relações sociais puramente humanas - e, portanto, que podemos transformar (Lessa; Tonet, 20II, p.9I).
\end{abstract}

A ideologia para os marxistas é conceituada como um poder ilusório, que encobre a lógica construtora das relações sociais, mostrando apenas o que é aparente e/ou senso comum, impedindo que se faça uma reflexão profunda da realidade. Ela é posta para os seres humanos pela superestrutura! É edificada pelos intelectuais orgânicos das classes dominantes para que não se desvele e/ou não se mostre o processo de produção em sua essência, que pertence a poucos, causando o que Lessa e Tonet (20II) afirmam como fixação da atividade social. O que a ideologia faz é retirar o poder dos homens comuns, a sua leitura crítica da realidade e a sua intencionalidade, que passam a ser atribuídas a seres transcendentes como o Espírito do Mundo ou Deus Histórico hegeliano - como se o mundo não fosse construído pelos homens. Assim, este é o conceito de ideologia, será utilizado aqui para responder às questões propostas e o objetivo deste artigo.

\title{
2.2. O ponto de virada na modernidade
}

$\mathrm{Na}$ introdução deste trabalho, pensadores como Capra (1999; 2003; 2007), Derrida (1999), Guattari (2001), Feyerabend (2003); Foucault (2001; 2010; 2011; 2012), Lyotard (1999), Santos (2001; 2007; 2010), entre outros, afirmam ser este um novo momento da sociedade, caracterizando-a de pós-moderna. Segundo Evangelista (2005), o iluminismo buscou livrar o ser humano do obscurantismo. A razão tinha como objetivo determinar a vida dos homens. Em suas palavras "É com o uso da razão, através do pensamento crítico, que o homem e a humanidade podem se emancipar e exercer a liberdade" (Evangelista, 2005, p.23). Porém, toda a promessa da razão como forma de emancipação do homem não sofreu um desenvolvimento integral. Pelo contrário, foi utilizada para expropriar o homem e a natureza, daí então seu caráter dialético e manipulatório. Adorno e Horkheimer (1999) mostram como a razão, de um pressuposto 
libertador, passou a representar o seu oposto, principalmente quando sofreu um processo de assepsia pelo positivismo.

Toda esta crítica sofrida pela razão, que foi apropriada pelo projeto burguês e que veio a ser denominada de razão instrumental pelos integrantes da Escola de Frankfurt, deu origem a uma onda irracionalista, de negação da razão, que passou a se edificar a partir de meados do século passado. Assim, conforme Goergen (200I), para Lyotard e McLaren vivese em uma época de rupturas:

\begin{abstract}
Desde um ponto de vista mais geral, na leitura de Peter McLaren, "a pósmodernidade pode ser descrita como uma época de coupure cultural e epistemológica, uma época na qual às fronteiras culturais e epistemológicas estão se desfazendo e os gêneros disciplinares se tornando indistintos". Trata-se da tentativa para compreender o fracasso da tradição iluminista em construir sujeitos autônomos que sejam capazes de superar a sua alienação. McLaren interpreta o movimento pós-moderno como um ataque direto à metafísica ocidental através da valorização do caráter histórico, imprevisível e não teleológico dos discursos locais e particulares, proferidos a partir das margens da tradição iluminista moderna (Goergen, 2001, p.27).
\end{abstract}

A crítica de Lyotard aos metarrelatos iluministas implica uma negação tout court da ideia de progresso histórico em direção a uma sociedade melhor através do uso correto da razão, conforme está inscrito no âmago do projeto moderno (Goergen, 200I, p.29).

Isto significa dizer que, para os pós-modernos, as metanarrativas (metafísica, a ciência positiva e o marxismo), onde há a ênfase na razão e na objetividade, como formas de se apropriar da realidade, cujos fundamentos começam a ser construídos na Grécia antiga, a partir dos séculos V e VI A.C, por Parmênides e por Heráclito, não mais servem para dar respostas consistentes aos grandes problemas humanos e passam a descartadas. Aliás, aprofundam os problemas! E quais seriam estes fundamentos que balizaram a edificação de todos os grandes sistemas, da metafísica à ciência, lançados por Parmênides e Heráclito?

Segundo Oliveira et al (2007), Parmênides afirma que o mundo das coisas materiais é inexistente, não possui uma existência real e verdadeira, é o mundo do não Ser. Para ele, o Ser subjaz por trás das aparências:

Para Parmênides, o Ser é - o que existe, o que está na realidade, que possui a característica de poder ser predicado, isto é, de ser qualificado como algo que é, e que pode ser adjetivado, a exemplo de algo que "é" feio, "é” bonito, "é” grande, "é" pequeno, etc - é sempre idêntico a si mesmo, imutável, eterno, imperecível, invisível aos nossos sentidos, porém visível aos nossos pensamentos, razão pela qual foi este o primeiro filósofo a afirmar que a aparência sensível das coisas não 
possui realidade, não existe real e verdadeiramente, não é, contrapondo-se assim o "Ser" ao "não-Ser", o que em termos lógicos, em nossos tempos, é concebido na produção do conhecimento científico, como a noção de verdadeiro e falso (Oliveira et al, 2007, p.27).

Nestes fundamentos parmedianos há a presentificação da verdade (aletheia), uma objetividade a ser perseguida, pois o Ser existe, subjaz por trás das aparências. Parmênides fundamentou a metafísica judaico-cristã, prenunciou, segundo Chauí (2005), os princípios da lógica formal - princípio da identidade; da não contradição e do terceiro excluído - e, através das regularidades inerentes ao Ser, criou uma sombra de homem que vaga pela Terra, o homem verídico, segundo Nietzsche (2010) e, mais a frente, com o espírito científico dos séculos XVII e XVIII, as regularidades passaram a ser quantificadas matematicamente na escalada do desvelamento do universo. Mas, de antemão, o que vem a ser esta sombra de homem que vaga pela Terra? Segundo Nietzsche (2010):

Para poder imaginar um mundo do verdadeiro e do ser, foi necessário em primeiro
lugar criar o homem verídico (inclusive o fato de que se julgue "verídico").
Simples, transparente, de acordo consigo mesmo, constante, sempre igual, sem
pregas, sem meios-termos, sem adereços, sem forma: aí esta o homem que concebe
um mundo do ser sob a forma de um "Deus" à sua imagem. Para que a veracidade
seja possível, é necessário que o homem só disponha de uma esfera bem própria,
bem restrita e bem respeitável; é necessário que a vantagem, em qualquer sentido
que seja tomada a palavra, caiba ao homem verídico (Nietzsche, 2oro, p.66).

Desta forma, construíram-se as bases e/ou fundamentos para que a ciência, principalmente, a positiva, com toda a sua pseudoneutralidade, fizesse uso destes postulados para se constituir a partir do século XV.

Heráclito vai se contrapor a esta ideia de logos de Parmênides. Para ele tudo flui. Nada permanece idêntico a si mesmo. O Ser de Parmenides aqui não faz sentido. O mundo é um fluxo contínuo e perpétuo no qual nada permanece idêntico a si mesmo e tudo se transforma pela luta dos contrários. Nada pode ser dito ou pensado. Oliveira et al (2007) afirma:

Nunca nos banhamos no mesmo rio, afirmava Heráclito, pois, ao fazermos isso pela segunda vez, o rio e nós mesmos já seremos outros. Assim, ao entrarmos em contato com o mundo, por meio da experiência sensorial, nós o percebemos como se tudo fosse estável e permanente, uma eterna reprodução dos fatos. Nosso pensamento, o Logos, sabe, porém, que nada permanece que tudo se transforma (Oliveira et al, 2007, p.27).

Os fundamentos de Heráclito, do movimento (vir-a-ser) e da contradição entre os opostos vão influenciar a dialética hegeliana - o Espírito do Mundo ou Deus Histórico. Hegel faz crítica à razão intemporal. Este Deus Histórico de Hegel nada mais é que a Razão Universal se manifestando. E como ela se manifesta? Segundo Chauí (1995):

Os conflitos históricos são a história da razão, buscando conhecer-se a si mesma e que, graças a tais conflitos, a filosofia pode chegar à descoberta da razão como 
síntese, unidade ou harmonia das teses opostas ou contraditórias (Chauí, 1995, p.82).

Esta Razão Universal nada mais é que a manifestação do Espírito do Mundo. Segundo Arantes (1999) e Chauí (1995), a história do mundo pretende que o espírito alcance o saber do que é verdadeiro e objetive esse saber e o realize, fazendo dele um mundo existente, manifestando-se objetivamente a si mesmo. A intencionalidade dos homens é descartada. Conforme Marcuse (1969):

\footnotetext{
A soberania do Espírito revela um mundo controlado pelas forças da história, em lugar de controla-las. A história revela-se como um patíbulo aonde foi sacrificado: a felicidade dos povos, a soberania dos Estados e a virtude dos indivíduos (Marcuse, 1969, p.213).
}

Marx aproveita-se do sistema hegeliano e constrói a Ontologia do Ser Social, criando uma antropologia, um ideal de homem - o homem socialista e racional, de método, o materialismo histórico-dialético e de valor. Marx com o seu posicionamento desloca o "Ser" presente, na filosofia de Parmênides e na filosofia de Hegel, para o homem, conforme se observa na Ontologia do Ser Social, aonde, segundo Lessa e Tonet (20II), o considera como um ser criador e construtor de sua história, levando em consideração o momento histórico. Para tanto, o conhecimento é fundamental. Com base no conhecimento [de como as coisas são] é possível determinar as tendências históricas predominantes e impulsionar as reais necessidades históricas da humanidade [de como as coisas devem ser], em direção à revolução socialista. Através de seu método e de suas análises, ele desvela todo o funcionamento do capitalismo do século XIX e dos modos de produção anteriores ao advento do capitalismo, como a infraestrutura (meios de produção) e a superestrutura (as instituições) contribuem para a sua manutenção e para a sua realização. Conceitos como mais-valia, fetiche da mercadoria e de ideologia, põem em xeque esta razão provinda de Parmênides à Hegel. O projeto iluminista passa a ser duramente questionado.

Apesar de Marx desvelar o funcionamento do sistema capitalista, depositando também como iluminista a sua fé na razão e, consequentemente, na emancipação do homem e da natureza, esqueceu-se de levar em consideração a subjetividade de cada ser humano. Loureiro (2005) afirma que o texto que causou um grande impacto na formação de Marcuse foi Manuscritos Econômicos e Filosóficos de Marx, pois o comunismo expresso não significava apenas a transformação radical do modo de produção capitalista, mas a emancipação do ser humano, que representa a emancipação dos sentidos e a transformação 
radical da consciência e do inconsciente, pois foi neste ponto as revoluções fracassaram. A partir deste texto a questão subjetiva é suprimida da obra de Marx.

Neste sentido, a metanarrativa marxiana contribuiu muito para o homem, elucidando como a opressão é produzida pelo sistema, conceitos como mais-valia, fetiche da mercadoria e ideologia, que faz parte do objeto deste trabalho, são essenciais para se entender como a realidade é falsificada, mas, ao deixar de lado a questão subjetiva, comportou-se como uma metafísica positiva.

Antes de Marx, o projeto racional, que a tudo poderia conhecer e nomear, já estava sofrendo vieses. Traços desta crítica a este projeto de mundo, de homem, de método e de valor, há muito já vinham sendo realizados por autores considerados modernos, como citados na introdução. Mas, um deles, produto do século XIX, rompeu com toda modernidade. Este filósofo foi Nietzsche (Azeredo-Dutra, 2010).

Segundo esta autora, apesar de Habermas afirmar que o projeto nietzschiano estaria circunscrito à modernidade em virtude de que "permaneceria subsidiado por uma consciência temporal e pelo apelo a racionalidade" (Azeredo-Dutra, 2010, p.I44), Nietzsche rompe com a tradição moderna - com o ideal de verdade e de objetividade herdadas do iluminismo - e vai ao encontro do que na pós-modernidade convencionou a se denominar de interpretandos, aonde o significante é enfatizado em detrimento do significado:

[...] Nietzsche compreende a vontade de potência, ao mesmo tempo, como verbo, ela é o interpretar, como sujeito, ela é o interprete, e como significação, enquanto expressão do significante e do significado, que se faz como exercer-se. Que no domínio do texto, enquanto imposição de perspectivas, não há leitura correta, mas imposição de uma interpretação. E, por fim, que o autor do Assim falava Zaratustra busca construir uma nova linguagem para expressar a singularidade doadora de sentidos que caracteriza sua exposição. Essas três dimensões que concernem, respectivamente, aos existentes enquanto exercer-se interpretativo, ao texto como abertura irredutível e a uma nova dimensão da linguagem permitem, a nosso ver, reivindicar para Nietzsche um ponto de virada com relação ao discurso filosófico da modernidade (Azeredo-Dutra, 2010, p.145).

O que significa dizer que o significante é enfatizado em detrimento do significado? Que não mais existe um sentido de objetividade na vida de todos. Cada qual, cada ser humano, constrói um significado a partir de sua experiência com a realidade, dependendo, sobretudo, de sua concepção de mundo, aonde o apelo ao emotivo é enfatizado por uma retórica carregada pelos sentimentos e não pela razão. Era assim que se fundamentava o 
discurso sofista na antiga Grécia! Segundo Chauí (2005) os socráticos faziam a crítica aos sofistas, pois:

\begin{abstract}
Os sofistas, diziam eles, operam apenas com opiniões (dóxai) contrárias, ensinando a argumentar persuasivamente tanto em favor de uma como de outra, dependendo de quem está pagando; não se interessam pela verdade (aletheia), que é sempre igual a si mesma e a mesma para todos. Sendo professores de opiniões, são mentirosos e charlatães. Além disso, continuavam os socráticos, recebendo dinheiro, o sofista perdia a liberdade de pensamento, sendo obrigado a conviver com quem quer que lhe pague $\mathrm{e}$ a ensinar o que lhe fosse exigido; mas à verdadeira sabedoria, julgava o grupo socrático, é algo que deve ser livremente compartilhado, e apenas entre amigos ou entre amantes, isto é, entre iguais (Chauí, 2005, p.163).
\end{abstract}

Se não há objetividade, se podemos defender opiniões muitas vezes conflitantes entre si, a realidade irá depender do significante, daquele que lhe confere e lhe dá um sentido através de seu discurso. Volta-se, desta forma, à época dos sofistas, encabeçados por Protágoras de Abdera que enfatizava, através de uma máxima, que: "O homem é a medida de todas as coisas, daquelas que são e daquelas que não são" (Chauí, 2005, p.16o). Ou seja, um puro relativismo!

Além da plurisemântica dos discursos, conceitos como "Vontade de Poder", "Eterno Retorno" e "Amor Fati” depositam no sujeito o papel central de sua relação com o mundo, uma relação pragmática e subjetivista, no valor que este sujeito dá ao mundo, apagando toda a objetividade que é característica dos grandes sistemas edificados na modernidade - da metafísica, do positivismo e do marxismo. Apesar de Nietzsche (2008) fundamentar o discurso de filósofos como Adorno e Horkheimer (1999), quando estes fazem críticas à ciência hodierna e ao positivismo, em seu processo de quantificação da realidade e de instrumentalização do mundo, enfim, no desvirtuamento da ciência, críticas estas que se encontram no aforismo XXVIII do Livro do Filósofo:

Não se trata de um aniquilamento da ciência, mas de seu domínio. Em todos os seus fins e em todos os seus métodos ela depende, para dizer a verdade, inteiramente de pontos de vista filosóficos, o que facilmente esquece. Mas a filosofia dominante deve também levar em consideração o problema de saber até que ponto a ciência pode se desenvolver: ela deve determinar o valor (Nietzsche, 2008, p.17).

Ele, Nietzsche, no Capítulo I do texto Além do Bem e do Mal, no aforismo III, faz incorrer em um processo de negação e de ruptura com o ideal de razão que foi edificada na modernidade e que Freud foi seu discípulo:

Do mesmo modo que o ato de nascer não influi no conjunto do processo da hereditariedade, tampouco o fato da "consciência" se opõe de qualquer modo 
decisivo ao instinto. Quase todo o pensamento consciente num filósofo é dirigido secretamente pelos seus instintos e forçado a seguir determinado caminho (Nietzsche, 2008, p.35).

Ora, nesta sentença situa-se o fundamento da psicanálise - a ação do inconsciente sobre o homem. A sua ênfase, como faz Nietzsche, além de outros conceitos presentes em sua obra, coloca-o como um filósofo que nega e rompe com toda a construção filosófica a partir de Sócrates, mesmo ele fazendo a crítica negativa ao pré-socrático Parmênides. Temos que considerar que este filósofo foi paradoxal em muitas passagens de suas obras. Se em alguns textos Nietzsche busca fazer uma apropriação da razão herdada da modernidade, como ocorre no Livro do Filósofo, servindo de base à crítica elaborada no início e meados do século XX pelos integrantes da Escola de Frankfurt, conceitos como "Vontade de Poder", como bem salientou Azeredo-Dutra (2010), como também o valor afirmativo da condução do homem pelos seus instintos, coloca-o como o filósofo que rompeu com a modernidade, pois levou a questão subjetiva ao extremo, representando este ponto de virada e uma pá de cal nas metanarrativas.

\subsection{A síntese: entre as críticas à modernidade e a ideologia pós-moderna}

\subsection{Principais críticas à modernidade pelos pós-modernos}

Segundo os autores pós-modernos citados na introdução deste trabalho, vivemos uma crise de paradigmas. As nossas concepções de mundo, homem, método e valor passam a ser duramente criticadas. Tendo como fio condutor o irracionalismo de Nietzsche, colocam o projeto iluminista em xeque. O projeto moderno, as grandes narrativas (metafísica, ciência e marxismo) não oferecem mais uma explicação para a problemática contemporânea, aliás, as agravam, pois dissolvem a subjetividade através de um discurso macroscópico (Evangelista, 2005).

Este discurso não possibilita explicar a plurissemântica que se processa na realidade social e natural, pois impede o aparecimento das linguagens - as condena. $\mathrm{O}$ ideal de homem que foi construído desde Parmênides até a contemporaneidade, o do homem verídico, dentro dos padrões da lógica formal, característico e presente nas metanarrativas - da metafísica ao marxismo - assassina o sujeito. Neste sentido, Guattari (200I) afirma que: "Os países ditos socialistas, por sua vez, também introjetaram os sistemas de valores "unidimesnsionalizantes" do Ocidente” (Guattari, 20oI, p.II). O homem verídico para os pós-modernos, construído a partir 
da metafísica parmediana e da ciência disciplinar, através da lógica formal, produz a homogeneização do sujeito e transforma a natureza num mero objeto de dominação do homem, um duro golpe contra toda diferença. Tudo que for alheio a esta fórmula primordial é considerado patológico. Por sua vez, a política da linguagem - que vem desconstruir e negar esta macroestrutura discursiva - encontra a sua base no estruturalismo e no pósestruturalismo. Segundo Evangelista (2005), a centralidade da subjetividade através ênfase da linguagem aconteceu por meio da generalização das categorias da linguística para o domínio antropológico, com Lévi-Strauss, e, em seguida, para "todas as principais estruturas da sociedade", com Foucault através de sua crítica a "normalidade" e a sua "ontologia do poder" (2002; 2010; 2011).

Derrida (2002) faz a crítica a metafísica parmediana e a sua visão de mundo, de homem e de natureza. Ele irá desconstruir o conceito Ocidental de animal, colocando-os como os "outros seres viventes" e mostrando que, mesmo não falando, é inegável o seu sofrimento. Uma questão tão importante, nos dias de hoje, em vista dos problemas derivados da ingestão de carnes, é a seleção de bactérias cada vez mais potentes, das pandemias e da questão ética que envolve o sofrimento dos animais, vulneráveis, que não têm voz. E isto é evidenciado através da visão utilitária que temos destes outros viventes, aos quais os denominamos desde o "Gênesis":

No decurso dos dois últimos séculos, estas formas tradicionais de tratamento do animal foram subvertidas, é demasiado evidente, pelos desenvolvimentos conjuntos de saberes zoológicos, etológicos, biológicos e genéticos sempre inseparáveis de técnicas de intervenção no seu objeto, de transformação de seu objeto mesmo, e do meio e do mundo de seu objeto, o vivente animal: pela criação e adestramento a uma escala demográfica sem nenhuma comparação com o passado, pela experimentação genética, pela industrialização do que se pode chamar a produção alimentar da carne animal, pela inseminação artificial maciça, pelas manipulações cada vez mais audaciosas do genoma, pela redução do animal não apenas à produção e a reprodução superestimulada (hormônios, cruzamentos genéticos, clonagem, etc) de carne alimentícia, mas a todas as outras finalidades a serviço de certo estar e suposto bem-estar humano do homem (Derrida, 2002, p.5I).

Essa violência contra os animais passa a ser denominada por ele de genocídio, que, em quase toda a história, foi dissimulada, esquecida e desconhecida:

Ninguém mais pode negar seriamente a negação. Ninguém mais pode negar seriamente por muito tempo que os homens fazem tudo o que podem para dissimular essa crueldade, para organizar em escala mundial o esquecimento ou o desconhecimento dessa violência que alguns poderiam comparar aos piores genocídios (existem também os genocídios animais: o número de espécies em via de desaparecimento por causa do homem é de tirar o fôlego). Da figura do 
genocídio não se deveria nem abusar nem se desembaraçar rápido demais. Porque ela se complica aqui: o aniquilamento das espécies, de fato, estaria em marcha, porém passaria pela organização e a exploração de uma sobrevida artificial, infernal, virtualmente interminável, em condições que os homens do passado teriam julgado monstruosas, fora de todas as normas supostas da vida própria aos animais assim exterminados na sua sobrevivência ou na sua superpopulação mesmo (Derrida, 2002, p.52).

Derrida (2002), citando Bentham, diz que a questão não significa apenas saber se o animal pode pensar, raciocinar e/ou falar. Refere-se, principalmente, se eles podem sofrer: "A questão prévia e decisiva seria a de saber se os animais podem sofrer. Can they suffer?" (Derrida, 2002, p.54). Esta questão é essencial, a partir dela, Derrida (2002) questiona:

Eles podem não poder? E o que dizer desse não poder? Da vulnerabilidade sentida a partir desse não poder? Qual é este não poder no âmago do poder? Qual é a qualidade ou a modalidade sentida a partir desse não poder? $O$ que levar em consideração? Que direito lhe conferir? O que isso nos concerne? Poder sofrer não é um poder, é uma possibilidade sem poder, uma possibilidade do impossível (Derrida, 2002, p.55).

O problema da vulnerabilidade, diante do não poder, diante da possibilidade do impossível, em nenhum momento, faz com que o ser humano pense nos animais e, na viacrúcis que atravessam todos os dias, em que o poder sofrer não é um poder, é uma possibilidade sem poder. À mercê de um poder parmediano, que sufoca todos os seus gritos - do interior dos laboratórios de pesquisas aos abatedouros - os animais nada significam, não têm representatividade! Derrida (2002) nos clama a compartilhar com os animais a finitude da vida:

A mortalidade que pertence a finitude propriamente dita da vida, à experiência da compaixão, à possibilidade de compartilhar a possibilidade desse não poder, a possibilidade dessa impossibilidade, a angústia desta vulnerabilidade e a vulnerabilidade desta angustia (Derrida, 2002, p.55).

$\mathrm{Na}$ política, Evangelista (2005) afirma que o surgimento de uma pluralidade de atores políticos deslocou a centralidade que estava reservada ao antigo antagonismo de classes. Para os pós-modernos, a pulverização do real, através do aparecimento de novos movimentos sociais como, por exemplo, o estudantil, o feminista, o homossexual, o ecológico, o pacifista, entre outros, só destaca a inoperância das grandes narrativas na resolução de problemática mundial. Há o estilhaçamento da "velha política de Estado" e a sua substituição pela "nova política”, pela contestação imediata e cotidiana de cada relação de dominação. O poder se desloca da macroestrutura para os níveis moleculares de ação, para 
as cartografias, para os ritornelos e para as pseudonarrativas. Toda esta pluralidade política, para os pós-modernos, estava sufocada pelas grandes narrativas:

O aparecimento de novos movimentos sociais - estudantil, feminista, homossexual, ecológico, pacifista, entre outros - deslocou, para segundo plano, o "velho movimento operário" nas lutas por transformações sociais. Surgiram "novos sujeitos políticos”, que questionam não só a ordem social estabelecida como o conjunto de instituições, inclusive aquelas que ocuparam o papel de questioná-la, como os sindicatos e os partidos operários. O cotidiano passou a ser descoberto "enquanto espaço de reprodução da dominação ou de resistência contra ela", produzindo-se a "politização do social” e o "estilhaçamento da política". A "velha política" foi substituída pela "nova política". Estes "novos" movimentos sociais atacaram o "ponto fixo da política", cristalizado em instituições políticas bem delimitadas e que gravitava, exclusivamente, em torno do Estado. A estratégia de "tomada de poder" caducou e cedeu lugar à "contestação imediata e cotidiana de cada relação de dominação" (Evangelista, 2005, p.16).

Além da crítica da homogeneização do homem, que se faz por meio da ênfase na linguagem no campo antropológico e social, aos antagonismos de classe que sufocavam o aparecimento de uma pluralidade de atores políticos, a transformação da natureza em um objeto para a ação do homem - evocando, por Derrida (2002), o genocídio dos animais - o discurso pós-moderno vai se fundamentar também nas novas descobertas da ciência a partir do início do século $\mathrm{XX}$, o que irá causar, para eles, uma ruptura epistemológica em toda razão provinda desde Parmênides à modernidade.

Segundo Capra (1999; 2002; 2007) e Santos (2007), no campo astronômico, a teoria da relatividade de Einstein enfatiza que a simultaneidade de acontecimentos distantes não pode ser verificada, pode tão só ser definida. É neste ponto arbitrária. Depende do ponto de vista do observador em relação a determinado evento. No nível das partículas elementares, a teoria de Heisemberg afirma que não é possível observar um objeto sem interferir nele. Não se podem reduzir simultaneamente os erros da medição da velocidade e da posição das partículas; o que for feito para reduzir o erro de uma das medições aumenta o erro da outra. Além destas, que ocorrem nos níveis astronômico e elementar, outras teorias vêm abalar os postulados da ciência clássica, provocando o rompimento do conceito de razão que foi cunhada a partir da ciência moderna, como o teorema da Incompletude de Gödel, que questiona o rigor da matemática, e o da teoria das Estruturas Dissipativas de Prigogine. Segundo ele, nos sistemas abertos, que funcionam as margens da estabilidade, nunca totalmente previsíveis, há o desencadeamento espontâneo de reações por mecanismos não lineares. Estas pressionam os sistemas e os conduzem a um novo estado macroscópico. 
Estas novas concepções da matéria e da natureza, aliadas à ênfase da subjetividade, através da ênfase das linguagens, do ensejamento de uma pluralidade de atores políticos e da crítica à visão utilitária de natureza, causam, para os pós-modernos, uma crise na concepção de verdade herdada da modernidade, porta-voz de um discurso anticientífico. Feyerabend apud Pessis-Pastenark (1993), conhecido como o "anarquista do conhecimento", vem simbolizar isto:

\begin{abstract}
Adeus à razão! Nada é objetivamente verdadeiro, uma vez que para todo enunciado, teoria ou ponto de vista concebido como verdadeiro, e com boas razões, existem argumentos suscetíveis de provar que uma visão alternativa é igualmente boa ou até melhor. Que digam que a ciência, da qual o Ocidente faz tanto caso, não é mais que uma tradição como outra qualquer, em nada superior às mitologias que ela simular criticar (Pessis-Pasternak, 1993, p.19).
\end{abstract}

Esta concepção de mundo, herdada da modernidade para os pós-modernos, não possibilita explicar a complexidade dos fenômenos sociais e naturais. Passa a ser considerada, inoportuna e imprópria e é a causa dos racismos, das discriminações e da destruição da natureza. Este posicionamento filosófico, que emergiu a partir de meados do século XX, tem epicentro em Paris e em seus arredores. Estas são as principais críticas dos pós-modernos à condição hodierna.

Baseado nestas críticas à modernidade, podemos dizer que estamos vivendo um novo momento da sociedade ou ele apenas representa uma ideologia no sentido dado a esta palavra pelos marxistas?

Antes de procurar responder a esta questão, torna-se necessário entender a filosofia do modo de produção capitalista neoliberal.

\title{
2.3.2. A filosofia do capitalismo neoliberal
}

O entendimento da filosofia do capitalismo neoliberal é essencial para responder o problema aqui levantado. Podemos dizer que é ela que fundamenta o funcionamento da economia do mundo contemporâneo. Para compreender alguns de seus pilares é necessário remetermo-nos a Friedrich Hayek, pois foi quem fundamentou as bases do capitalismo neoliberal.

Segundo Butler (1987), Hayek foi fundador das bases do neoliberalismo. Forneceu substancial provisão aos adeptos da livre sociedade, na declaração que fez sobre os princípios desta, em Os fundamentos da Liberdade e em Direito, Legislação e Liberdade, estabeleceu 
as bases filosóficas, legais e constitucionais para a delicada estrutura da ordem social e liberal. Hayek resgata e redefine dois princípios e as práticas do liberalismo em tempos modernos: o neoliberalismo.

O primeiro princípio é a incapacidade de apropriação da realidade. Ele afirma que a realidade e a sociedade são muito complexas, bem acima da capacidade de compreensão de uma só mente e impossíveis de serem planejadas (BUTLER, 1987).

O segundo princípio, que se relaciona com a liberdade individual, é extremamente necessário para que a sociedade se desenvolva e impeça qualquer tentativa contra a liberdade, pois irá privar a ordem social de sua habilidade para alocar recursos com eficiência para superar desafios e problemas. $\mathrm{O}$ mercado deve ser regulado por uma mão invisível. O livro além de fundamentar as bases filosóficas para a sociedade neoliberal, também examina a estrutura legal necessária para apoiar a sociedade liberal, quanto ao estado de direito: tratar as pessoas com igualdade e não como se fossem peças de um jogo de xadrez econômico (BUTLER, 1987).

Conforme Butler (1987), esta liberdade é do tipo egoísta, em que os homens se organizam em busca de suas pretensões econômicas. Este tipo de liberdade é o bem maior que a sociedade neoliberal pode ter. Baseado nela, podemos inferir que os homens, que não conseguem se realizar no mercado, são culpados pelos seus fracassos. Este conceito de liberdade produz uma assepsia nas relações econômicas, sociais e políticas, que justifica a marginalização de milhares de pessoas que não conseguem encontrar meios de sobrevivência num sistema.

Isto nos traz até o conceito de liberdade presente na física social de Locke apud Capra (1999). Ele comparava o estágio de agitação das moléculas de um gás à função dos indivíduos em uma sociedade, dizendo que todos deixados em liberdade ou sem uma força coercitiva que agisse sobre eles tenderiam ao equilíbrio.

\subsubsection{Pós-modernidade: um novo momento da sociedade ou ideologia para os marxistas}

Em relação ao exposto, algumas implicações críticas vão ser tecidas quanto ao discurso pós-moderno. Não se pode fugir à crítica pós-moderna, que enfatiza a subjetividade, um novo entendimento do homem, através das linguagens, da política e do social, da ciência e da questão ambiental. A pós-modernidade traz estas questões de forma latente, questões 
estas que não foram resolvidas pela modernidade e estão longe de serem encaminhadas neste momento tão difícil que estamos vivendo.

A questão que se coloca, após toda a discussão empreendida, é: a pós-modernidade é um novo momento da sociedade ou ideologia para os marxistas?

Em primeiro lugar, não perdendo de vista o funcionamento do sistema capitalista neoliberal, através de suas teses centrais - a incapacidade da realidade ser apropriada e a liberdade individual - torna-se necessário pontuar algumas críticas à subjetividade e aos discursos plurais.

Conforme Evangelista (2005), com relação à ênfase à subjetividade e a emergência de uma pluralidade de atores políticos e de discursos, todos os princípios da racionalidade moderna como a ciência, a verdade, a revolução, a felicidade, entre outros, deram lugar às cartografias, às pseudonarrativas, ao microscópio, ao efêmero, ao singular, ao imaginário enfim, às biografias. Por este viés, há completa perda de objetividade: o significante é hipertrofiado em detrimento do significado:

Há uma rejeição pelas grandes sínteses intelectuais, pelo conhecimento das primárias, pela busca do sentido de história, que passa a ser denominada pela indeterminação e pela ação de sujeitos autoconstituintes do processo histórico. Declara-se a incapacidade dos "velhos esquemas interpretativos" e proclama-se a necessidade da elaboração de "novos paradigmas", cujas "novas metodologias" devem estar centradas no "cotidiano não estruturado", heterogêneo e pluralista dos processos sociais. Assim, foi deflagrada uma colossal onda irracionalista, cujo epicentro está em Paris e seus arredores. Esse "novo" irracionalismo tomou corpo com as reflexões em torno dos acontecimentos em maio de 1968, na França. E pode ser caracterizado, resumidamente, pela desreferencialização do real, pela dessubstancialização do sujeito e pelo descentramento da política (Evangelista, 2005, p.25).

Através deste posicionamento, aonde o microdiscurso é enfatizado, há uma perda de uma leitura totalizante da realidade, pois o discurso se transforma em biografias e a possibilidade de um projeto para a humanidade é bloqueada. Se não há uma leitura totalizante e integradora da realidade - papel reservado, principalmente, ao marxismo - que mostre quem é o grande culpado pela degradação dos modos de vida humanos e naturais, o irracionalismo se propaga. A realidade passa a ser diluída em interpretações subjetivas, a ênfase recai sobre o significante. Segundo Evangelista (2005):

Se for impossível a descoberta de um sentido no processo histórico social, que possa ser racionalmente apreendido instaura-se o império da incognoscibilidade com a relativização de todo conhecimento, permitindo uma multiplicidade inesgotável de interpretações, todas válidas. A realidade teria como característica essencial o seu caráter fragmentário, que impede qualquer possibilidade de síntese ou totalização, 
que apreenda o real. É, daí, que advém o jogo da crítica ao marxismo. O marxismo, ao contrário dessas outras concepções, reivindica para si a condição de pensamento totalizante e integralizador, reconhecendo-se como herdeiro e continuador das grandes sínteses do pensamento moderno. Mais: propõe-se a ser a expressão teórica do movimento dialético do real e que, por isso, é o único capaz de conhecer e explicar, racionalmente, a totalidade histórica. Então, é identificado pelos teóricos "pós-modernos" como um "paradigma" ultrapassado e preso a uma concepção determinista e teleológica de história (Evangelista, 2005, p.31).

Evangelista (2005) afirma que a pretensa politização do social e o descentramento da política, em que se ensejariam uma pluralidade de atores sociais, dotados de condições de atuar em busca da transformação social, encobrem ideologicamente e ilusoriamente as determinantes sociais: o que é a sociedade de classe no mundo do capital:

\begin{abstract}
Um equívoco elementar daqueles que defendem que a marca da contemporaneidade reside na "politização do social" e no consequente "descentramento da política", que ensejariam uma pluralidade de sujeitos sociais com igual capacidade de protagonizar os processos de transformação social, está no desconhecimento ou na desconsideração da essencialidade que a dominação de classe assume na sociedade do capital. Essa forma de dominação exige um aparato especializado na sua regulação e repressão, cujas estruturas estão condensadas, centralmente, no Estado burguês (Evangelista, 2005, p.33).
\end{abstract}

Esta análise vai ao encontro do que Azeredo-Dutra (2010) denominou de interpretandos nietzschianos, um discurso em que a universalidade e a objetividade cedem lugar ao fragmentário, ao efêmero, ao irracional. Assim, dilui-se qualquer tentativa de uma apropriação crítica da realidade, daquilo que o sistema tenta esconder em um lugar secreto o capitalismo neoliberal. É isto que constata Arce (2000):

A este quadro caótico articula-se o universo ideológico pós-moderno com seu irracionalismo, negando à continuidade temporal, a história, a universalidade. A realidade passa a constituírem-se por diferenças, alteridades, subgrupos com subculturas e micro-poderes invisíveis que disciplinam e regulam a vida social (Chauí, 1993, p.22-23); A subjetividade toma o lugar da objetividade e mergulhado em si mesmo, o indivíduo torna-se incapaz de perceber o conjunto de medidas e ideias que regem o cotidiano. $O$ pós-modernismo acaba por reforçar o individualismo cego e exacerbado apregoado pelas políticas neoliberais. Neste contexto pós-moderno da morte da razão, avulta aos indivíduos a ideia de que o presente é continuo, sem rupturas, sem lutas, sem slogans, levando a realidade à total fragmentação impossível de ser apreendida em sua "à valorização do fragmentário, do microscópico, do singular, do efêmero, do imaginário". Retirando-se o sentido da história o futuro deixa de ser preocupação para totalidade (Frederico, 1997). Também analisando o ideário pós-moderno, Evangelista (1997, p.24) mostra que, nele, ciência, verdade, progresso e revolução cedem lugar os indivíduos, que, mergulhados no cotidiano fragmentado, trocam as grandes lutas da humanidade por "pequenas lutas", transformações particularizadas de cotidianos particularizados, "o imediato toma o lugar do mediato" e o ser humano perde a noção de humanidade (Arce, 2000, p.48). 
Estas são as teses que se relacionam e reafirmam as leis do mercado elencadas acima, em que pese - a liberdade individual e a incapacidade de um projeto para a humanidade. Quando a pluralidade de discursos e as cartografias tomam a centralidade do político e do social, ocorre a diluição do macrodiscurso, que é aquele que permite a apropriação crítica do processo capitalista neoliberal e de como este se realiza.

O outro perigo da emergência desta plurissemântica linguística é o relativismo cultural. As culturas apresentam valores e atitudes que são aceitos pelos componentes de um grupo e que permitem que ele se mantenha como unidade. Apesar de em sua grande parte representarem valores e atitudes que a ressignificam, dão sentido à existência de cada indivíduo e da cultura de forma geral, muitas de suas práticas podem contribuir para o etnocentrismo, para o sofrimento e morte dos homens, dos animais e da natureza de maneira geral, afetando-os diretamente e contribuindo, decisivamente, para o colapso do sistema, quando este momento pede um pouco mais de alma. Por isso, todo relativismo cultural deve passar pelo crivo do humanismo, sem o qual pode significar barbárie. É bom deixar bem claro as culturas, como toda a realidade, se transformam.

Neste sentido, uma pergunta se faz mais que necessária: qual a eficiência das pseudonarrativas e/ou dos discursos moleculares diante do capitalismo neoliberal? Promovem, quando muito, um reajuste no sistema, impedindo sua leitura crítica e a formatação de um projeto filosófico, antropológico, político, social e econômico para a humanidade.

São diante destes fatos que o discurso pós-moderno se comporta apenas como uma ideologia, conforme o conceito atribuído a este termo pelos marxistas no início deste trabalho por Chauí (1995) e Lessa e Tonet (2011). Ao diluir o discurso contrário ao capitalismo, que é produto da modernidade, tendo seu início ainda na baixa idade média, a pós-modernidade reproduz um estado ilusório, o falseamento da realidade, pois encobre e naturaliza as relações de classe e transforma as lutas universais (homens e animais, natureza) em meras abstrações particulares.

Mas, será que a modernidade, através de suas metanarrativas, não produziu outras formas de se situar no mundo, enfatizando processos emancipatórios do homem, dos animais e da natureza? 
Há muitas produções na modernidade que perpassam toda a cultura humana, que podem e devem ser utilizadas para dar outro direcionamento à existência do homem e do planeta. Um exemplo é o marxismo, que, apesar de suas limitações, aonde em alguns lugares, uma minoria de "homens predestinados" solapou todas as bases democráticas e se transformou em ditadores, pode oferecer estes caminhos. Sua lógica, a dialética, articulada aos princípios da lógica formal, produz o conhecimento interdisciplinar, que, aplicado à realidade, pode contribuir para que ela não seja falseada e se reconstrua sob outras bases que não provoquem o colapso do mundo. Estes princípios respondem a praticamente a todas estas questões levantadas postas pela pós-modernidade, sem perder de vista uma leitura universal, integradora, da realidade, que leve em conta o planejamento da humanidade:

A) Princípio da unidade na diversidade: apesar das diferenças, homens, animais e plantas dividem um mesmo planeta, uma mesma história, e são responsáveis por ele, compartilham juntos: o acaso e a finitude da vida;

B) Princípio da contradição: toda realidade é contraditória ou dialética. Quando não admite a contradição é fascista em sua essência. Quando não permite a síntese e a superação dos predicados postos e negados, entra em colapso. Continuar sobre estas bases filosóficas é provocar o suicídio da vida;

C) Princípio da síntese de múltiplas determinações: ele traz um apreço enorme para a vida, pois enfatiza que, apesar do homem estar condicionado pelo sistema, pode saltar e ser sujeito de sua história. Nele está implícito no pensamento existencialista de Sartre: "Não importa o que fizeram com você, mas sim o que você fez com o que fizeram de você”. A vida só está convidando o ser humano a ser e, apesar de tanta escuridão, a luz ainda se estende no final do túnel.

\section{CONSIDERAÇÕES FINAIS}

Apesar de alguns autores pós-modernos, citados aqui, realizarem a crítica as metanarrativas da modernidade, que afirmam: dissolvem o sujeito, produzem - através da ciência de base positiva e dos sistemas capitalistas e socialistas - todas as formas de discriminações e de racismos, a exploração e a expropriação do homem e da natureza, o holocausto animal que não têm escolhas diante do inevitável, este artigo procurou evidenciar que a pós-modernidade veio a situar-se como uma "pseudonarrativa" que reafirma o sistema 
capitalista, pois ao enfatizar as particularidades através de uma postura subjetivista perde o seu caráter universal que é a apropriação crítica do sistema, do macro e passa a naturalizar as relações de classe e a degradação ambiental, que são parte de uma luta unívoca aonde todas as outras devem estar subordinadas. Ao enfatizar os microdiscursos, decorrentes da pulverização do político e do social, a pós-modernidade acentua, por meio de um véu negro, a exploração e expropriação do homem e da natureza, se constitui em uma ideologia - que produz e reproduz assim, um estado ilusório que envolve a realidade.

Retomando a questão inicial, a pós-modernidade é um novo momento da sociedade ou é uma ideologia para os marxistas pode-se dizer que é uma ideologia, pois, ela vela a identidade do grande culpado pela situação crítica atual: o capitalismo neoliberal, que é também produto da modernidade. Apesar de seu ideário penetrar fortemente nas várias áreas da sociedade, por exemplo, a educação e a ciência, seu discurso de aparente resistência se revela um simulacro que falseia a realidade e produz uma perda completa de referências e de objetividade, existentes nas metanarrativas, como o marxismo, que podem oferecer uma apreensão do real.

\section{REFERÊNCIAS BIBLIOGRÁFICAS}

ADORNO, T; HORKHEIMER, M. Dialética do esclarecimento. São Paulo: Zahar, 2006. 223p.

ARCE, A. 200o. A formação de professores sob a ótica construtivista: primeiras aproximações e alguns questionamentos. In: Duarte, N. Sobre o construtivismo. Campinas: Editora autores e associados.

AZEREDO-DUTRA, V. Nietzsche e a modernidade. Cadernos Nietzsche, São Paulo, n.27, p.I43-168, 2010.

BUTLER, E. A contribuição de Hayek às ideias políticas e econômicas de nosso tempo. Rio de Janeiro: Editora Nórdica, 1987.

CAPRA, F. O ponto de mutação. São Paulo: Cultrix, I999. 
CAPRA, F. 2007. A teia da vida. São Paulo: Cultrix, 2007.

CHADDAD, FR. Parâmetros curriculares nacionais, temática ambiental e razão instrumental: uma análise de seus fundamentos filosóficos. o5 de fevereiro de 2016. I87 f. Mestrado em Educação Escolar - UNESP, ARARAQUARA, 2016.

CHAUÍ, M. Convite à filosofia. São Paulo: Ática, 1995.

CHAUÍ, M. Introdução à história da filosofia: dos pré-socráticos a Aristóteles. São Paulo: Companhia das Letras, 2002.

DERRIDA, J. O animal que logo sou. São Paulo: Editora Unesp, 2002.

EVANGELISTA, EJ. Crise do marxismo e irracionalismo pós-moderno. zed. São Paulo: Cortez, 2005.

FOUCAULT, M. A ordem do discurso. São Paulo: Edições Loyola, 200 .

FOUCAULT, M. Microfísica do poder. São Paulo: Graal, 2 oı.

FOUCAULT, M. História da sexualidade: a vontade de saber. São Paulo: Graal, 2011.

FREUD, S. Cinco lições de psicanálise. In: Os pensadores. São Paulo: Abril Cultural, 1978.

GOERGEN, P. Pós-modernidade, ética e educação. Campinas: Editores Autores Associados, 200I.

GUATTARI, F. As três ecologias. Campinas: Papirus, 200 .

KANT, I; SCHOPENHAUER, A.O pensamento vivo. São Paulo: Martins, 1965. 
KANT, I. Crítica da razão pura. São Paulo: Nova Cultural, 1999.

LESSA, S; TONET, I. Introdução a filosofia de Marx. São Paulo: Expressão popular, 201 I.

LÖWY, M. As aventuras de Karl Marx contra o barão de Münchhausen. São Paulo: Cortez, 2003.

LYOTARD, JF. Moralidades pós-modernas. Campinas: Papirus, 1993..

MARCONDES, D. Textos básicos de filosofia: dos pré-socráticos a Wittgenstein. 2 ed. Rio de Janeiro: Jorge Zahar, 2000.

MARCUSE, H. Razão e revolução. Rio de janeiro: Editora Saga, ig69.

MARCUSE, H. O homem unidimensional. São Paulo: Edipro, 2015.

MARTINS, GA. Manual para elaboração de monografias e dissertações. São Paulo: Atlas, 1994 .

NIETZSCHE, F. O livro do filósofo. São Paulo: Editora Escala, 2007.

NIETZSCHE, F. Além do bem e do mal. São Paulo: Martin Claret, 2008.

OLIVEIRA, EM; ALMEIDA, JLV; ARNONI, MEB. Mediação dial tica na educação escolar: teoria e prática. São Paulo: Edições Loyola, 2007.

OLIVEIRA, EM; BUCHALA, AS. 2007. Educação, meio ambiente e desenvolvimento humano: da crise do paradigma científico à necessidade da dialética. In: BARBOSA, RL (Org). Formação de Educadores - artes e técnicas - ciências e políticas. São Paulo: Editora Unesp, 2007, v.I, p.331-35I. 
ROUSSEAU, JJ. Discurso sobre a origem e os fundamentos da desigualdade entre os homens. São Paulo: Martin Claret, 2010.

SAFRANSKI, R. Schopenhauer e os anos mais selvagens da filosofia. São Paulo: Geração Editorial, 2012.

SANTOS, BS. Pela mão de Alice: o social e o político na pós-modernidade. São Paulo: Cortez, 20oI.

SANTOS, BS. Um discurso sobre as ciências. Is ed. Porto: Afrontamento, 2007.

SANTOS, BS. Introdução a uma ciência pós-moderna. São Paulo: Graal, 2010.

SCHOPENHAUER, A. Sobre a vontade na natureza. Rio de Janeiro: L\&PM POCKET, 2013. 